\title{
Conformational Effects on Peptide Aggregation in Organic Solvents: Spectroscopic Studies of Two Chemotactic Tripeptide Analogs
}

\author{
P. ANTONY RAJ and P. BALARAM, ${ }^{*}$ Molecular Biophysics Unit, \\ Indian Institute of Science, Bangalore 560 012, India
}

\begin{abstract}
Synopsis
The aggregation behavior of the chemotactic peptide analogs, Formyl-Met-Leu-PheOMe (1) and Formyl-Met-Aib-Phe-OMe (2), has been studied in chloroform and dimethylsulfoxide over the concentration range of $0.2-110 \mathrm{~m} M$ by ${ }^{1} \mathrm{H}-\mathrm{nmr}$ spectroscopy. Both peptides associate in $\mathrm{CDCl}_{3}$ at concentrations $\geq 2 \mathrm{mM}$, while there is no evidence for aggregation in $\left(\mathrm{CD}_{3}\right)_{2} \mathrm{SO}$. Analog 1 adopts an extended conformation in both solvents favoring association to form $\beta$-sheet structures. A folded, $y$-turn conformation involving a $3 \rightarrow 1$ hydrogen bond between Met $\mathrm{CO}$ and Phe $\mathrm{NH}$ is supported by ${ }^{1} \mathrm{H}-,{ }^{13} \mathrm{C}-\mathrm{nmr}$, and ir studies of analog 2. The influence of backbone conformation on the ease of peptide aggregation is demonstrated by ir studies in $\mathrm{CHCl}_{3}$ and $\mathrm{CD}$ studies in dioxane.
\end{abstract}

\section{INTRODUCTION}

The conformational analysis of peptides in solution by spectroscopic techniques is often complicated by the problem of peptide aggregation." ' The influence of peptide association on ${ }^{1} \mathrm{H}-\mathrm{nmr}$ parameters ${ }^{6}$ and the demonstration of the presence of aggregates in chloroform solutions of small protected peptides by vapor-phase osmometry have been the focus of recent investigations. ${ }^{7,8}$ An analysis of aggregation effects on spectral parameters and the possible role of monomer conformation on the mode and facility of intermolecular association would be of value in developing spectroscopic methodology to probe the structural characteristics of peptide aggregates. With this end in view, we have chosen to examine the peptides For-Met-Leu-Phe-OMe (1) (For $=$ formyl, $\mathrm{OMe}=$ methoxy) and For-Met-Aib-Phe-OMe (2) by $\mathrm{nmr}\left({ }^{1} \mathrm{H}\right.$ and ${ }^{13} \mathrm{C}$ ), and $\mathrm{CD}$ methods, in organic solvents, over a range of concentrations. These peptides constitute biologically-active analogs of the chemotactic tripeptide, For-Met-Leu-Phe-OH, which has been shown to stimulate neutrophil chemotaxis and selective release of lysosomal enzymes. $^{9-11}$ Esterification of the $\mathrm{C}$-terminal carboxylic acid group has marginal effects on biological potency. ${ }^{10}$ Earlier ${ }^{1} \mathrm{H}$ - and ${ }^{13} \mathrm{C}-\mathrm{nmr}$ studies of For-Met-Leu-Phe-OH in dimethylsulfoxide have been interpreted in terms of an unassociated peptide in an extended $\beta$-sheet conformation. ${ }^{12}$ In peptide 2 , the central Leu residue has been replaced by

\footnotetext{
${ }^{*}$ To whom correspondence should be addressed.
} 
an a-aminoisobutyryl(Aib) residue in order to facilitate chain reversal, resulting in stabilization of a folded backbone conformation. This feature may be anticipated, in view of the well-established tendency of Aib residues to favor folded $\beta$-turn structures in small peptides. ${ }^{13-16}$ The choice of peptides $\mathbf{1}$ and $\mathbf{2}$ permits a study of aggregation effects on two peptides having sequences with markedly different tendencies to adopt folded conformations. A comparative study of peptides $\mathbf{1}$ and $\mathbf{2}$ is also relevant, since it has been shown that replacement of Leu by Aib at position 2 leads to retention of biological activity. ${ }^{17}$

\section{MATERIALS AND METHODS}

The peptides For-Met-Leu-Phe-OMe (1), For-Met-Aib-Phe-OMe (2), For-Met-Leu-Leu-OMe (3), and For-Met-Aib-Leu-OMe (4) were synthesized by standard solution-phase procedures using dicyclohexylcarbodiimide (DCC) or DCC-1-hydroxybenzotriazole-mediated couplings. ${ }^{18}$ $t$-Butyloxycarbonyl (Boc) and methyl ester groups were used for amino and carboxyl group protection, respectively. The Boc group was cleaved from the corresponding tripeptide methyl esters by treatment with $98 \%$ formic acid. Evaporation of formic acid, followed by addition of freshly distilled acetic anhydride to the residue, yielded the formyl peptides in good yields (75-90\%). All peptides were purified by column chromatography on silica gel using $\mathrm{CHCl}_{3}$ or $2 \% \mathrm{CH}_{3} \mathrm{OH}-\mathrm{CHCl}_{3}$ as eluants. Peptides were obtained as white solids, homogeneous by tlc, and yielded $270-\mathrm{MHz}^{1} \mathrm{H}-\mathrm{nm}$ r spectra fully consistent with their structures. Peptides were also found to be homogeneous by HPLC on a reverse-phase RP-18 Lichrosorb column, using methanol-water linear gradient elution and employing an LKB HPLC system (55-75\% MeOH in $15 \mathrm{~min}$; flow rate, $0.8 \mathrm{~mL} / \mathrm{min}$; retention time $1,13.4 \mathrm{~min} ; 2,11.6$ $\min )$.

${ }^{1} \mathrm{H}-(270-\mathrm{MHz})$ and ${ }^{13} \mathrm{C}-(67.89-\mathrm{MHz}) \mathrm{nmr}$ spectra were recorded on a Bruker WH-270 spectrometer at the Sophisticated Instruments Facility, Bangalore, under conditions described elsewhere. ${ }^{19,20}$ Chemical shifts are expressed as 6 ( $\mathrm{ppm}$ ) downfield from internal tetramethylsilane for both ${ }^{1} \mathrm{H}$ - and ${ }^{13} \mathrm{C}$ - spectra. The ir spectra were recorded on a Perkin-Elmer model 297 spectrometer. Solutions were prepared in dry $\mathrm{CHCl}_{3}$ and spectra recorded using pathlengths of $1-7.5 \mathrm{~mm}$. CD spectra were recorded on a Jasco 5-20 spectropolarimeter using 1-mmpathlength cells. CD band intensities are expressed as molar ellipticities $[\theta]_{M}$ in $\operatorname{deg} \mathrm{cm}^{2} \mathrm{dmol}^{-1}$.

\section{RESULTS AND DISCUSSION}

\section{${ }^{1}$ H-NMR Studies}

The dependence of peptide NH chemical shifts $(\delta)$ and their temperature coefficients $(d \delta / d T)$ on concentration, were determined in $\mathrm{CDCl}_{3}$ and $\left(\mathrm{CD}_{3}\right)_{2} \mathrm{SO}$ for 1 and 2 . The $\mathrm{NH}$ resonances were readily 


\section{PEPTIDE}

assigned by spin decoupling experiments, which established the connectivities between the $\mathrm{C}^{\beta} \mathrm{H}_{2}, \mathrm{C}^{a} \mathrm{H}$ and $\mathrm{NH}$ resonances for each residue. Figures 1 and 2 illustrate the variations in $\delta$ values obtained for the $\mathrm{NH}, \mathrm{C}^{\alpha} \mathrm{H}$, and formyl resonances in $\mathbf{1}$ and $\mathbf{2}$ in the two solvents. The concentration dependences of the $d \delta / d T$ values of the $\mathrm{NH}$ groups are illustrated in Fig. 3. In peptide 1, the only $J_{\mathrm{HNC} \text { a }}$ value that showed a significant change with concentration in $\mathrm{CDCl}_{3}$ was Met (1)NH, varying from $7.7 \mathrm{~Hz}$ at $0.2 \mathrm{~m} M$ to $9.2 \mathrm{~Hz}$ at $110 \mathrm{~m} M$. Smaller changes were observed for Leu $\mathrm{NH}$, while the $J_{\mathrm{HNCCH}^{\circ}}$ value for Phe $\mathrm{NH}$ was concentration independent. In peptide 2 , the $J$ values were largely concentration independent over the range studied. In view of these observations, $J$ values have not been used in subsequent analysis of aggregation effects.

A feature of the data in Figs. 1-3 is that $\delta$ and $d \delta / d T$ values for $\mathrm{NH}$ groups are concentration independent for both peptides in $\left(\mathrm{CD}_{3}\right)_{2} \mathrm{SO}$ over the range 2-100 $\mathrm{mM}$. This suggests that the peptides exist as solvated monomers in $\left(\mathrm{CD}_{3}\right)_{2} \mathrm{SO}$. In contrast, in $\mathrm{CDCl}_{3}$, all three $\mathrm{NH}$ groups in 1 show pronounced concentration dependences, moving
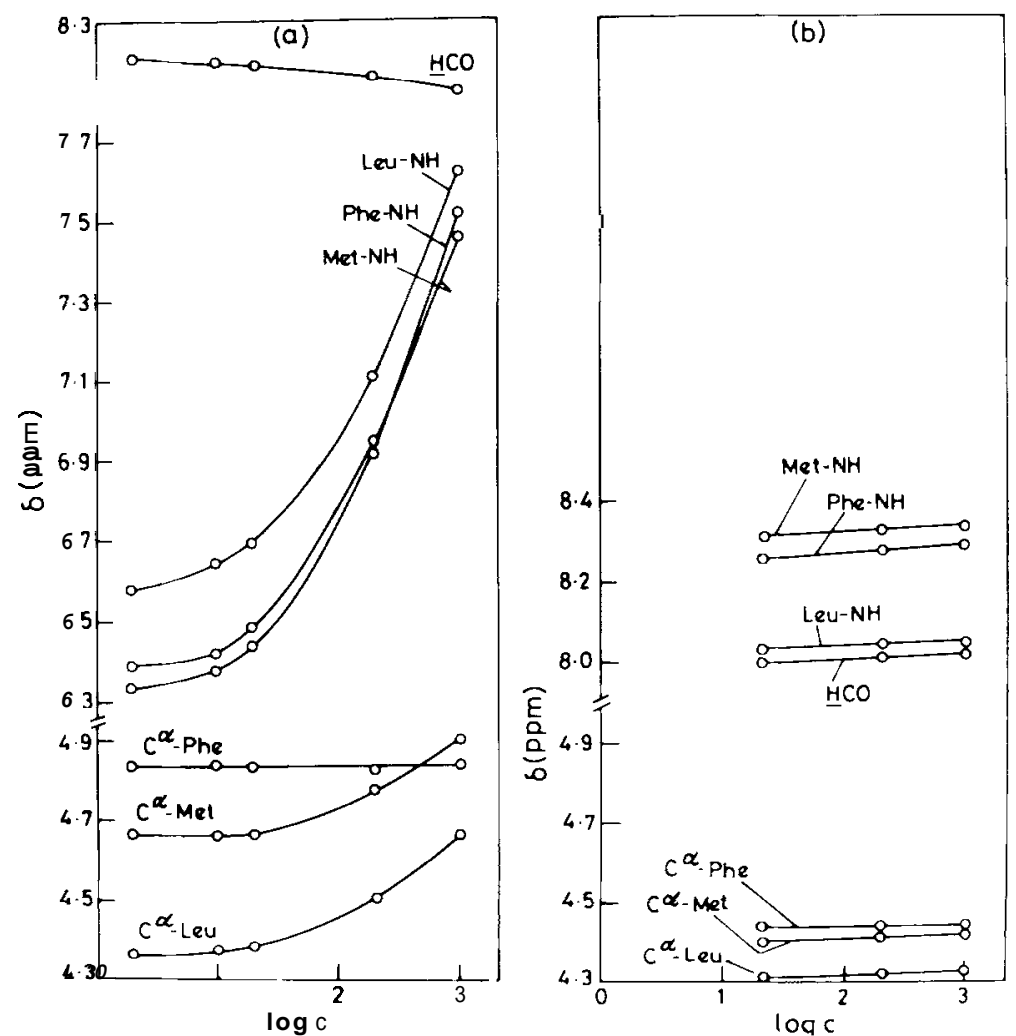

Fig. 1. Concentration dependence of chemical shifts $(\delta)$ for various resonances in For-Met-Leu-Phe-OMe (1) in (a) $\mathrm{CDCl}_{3}$ and (b) $\left(\mathrm{CD}_{3}\right)_{2} \mathrm{SO}$. Abscissa expresses concentration as $\log C$, where $C$ is the molar concentration of peptide, $\times 10^{4}$ : 


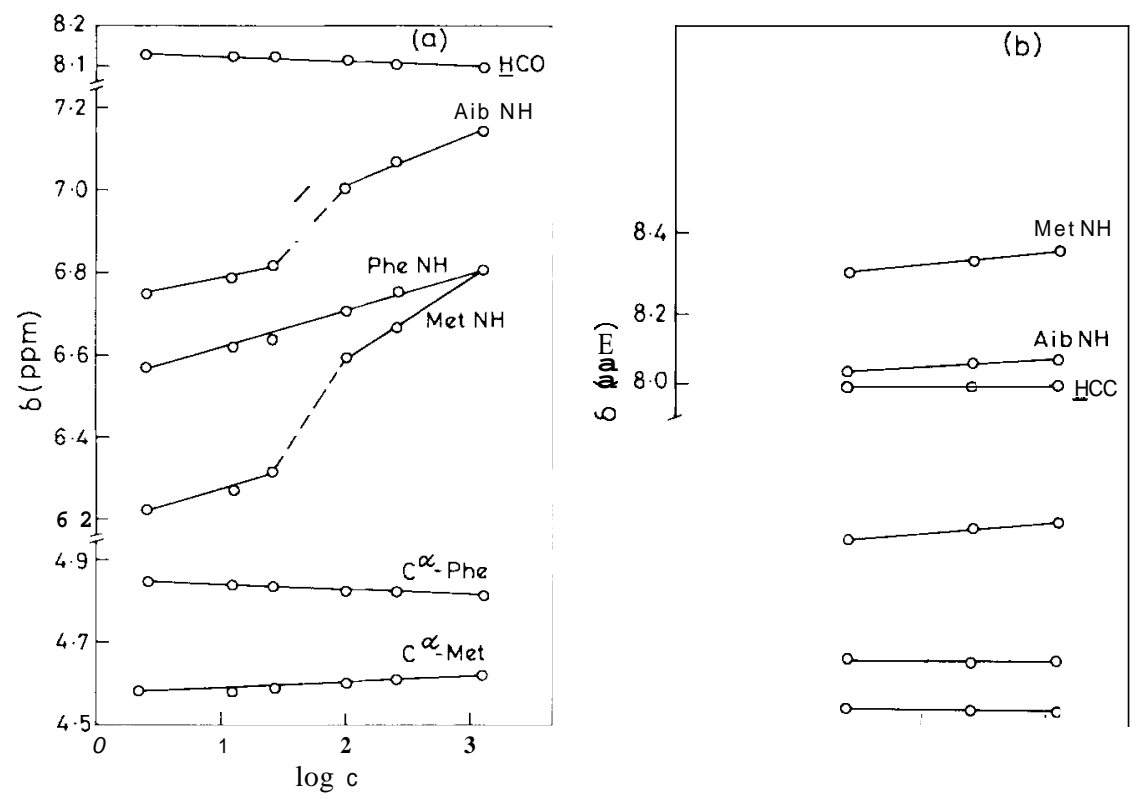

Fig. 2. Concentration dependence of chemical shifts $(\delta)$ for various resonances in For-Met-Aib-Phe-OMe (2) in (a) $\mathrm{CDCl}_{3}$ and (b) $\left(\mathrm{CD}_{3}\right)_{2} \mathrm{SO}$. Abscissa expresses concentration as $\log C$, where $C$ is defined as in Fig. 1.
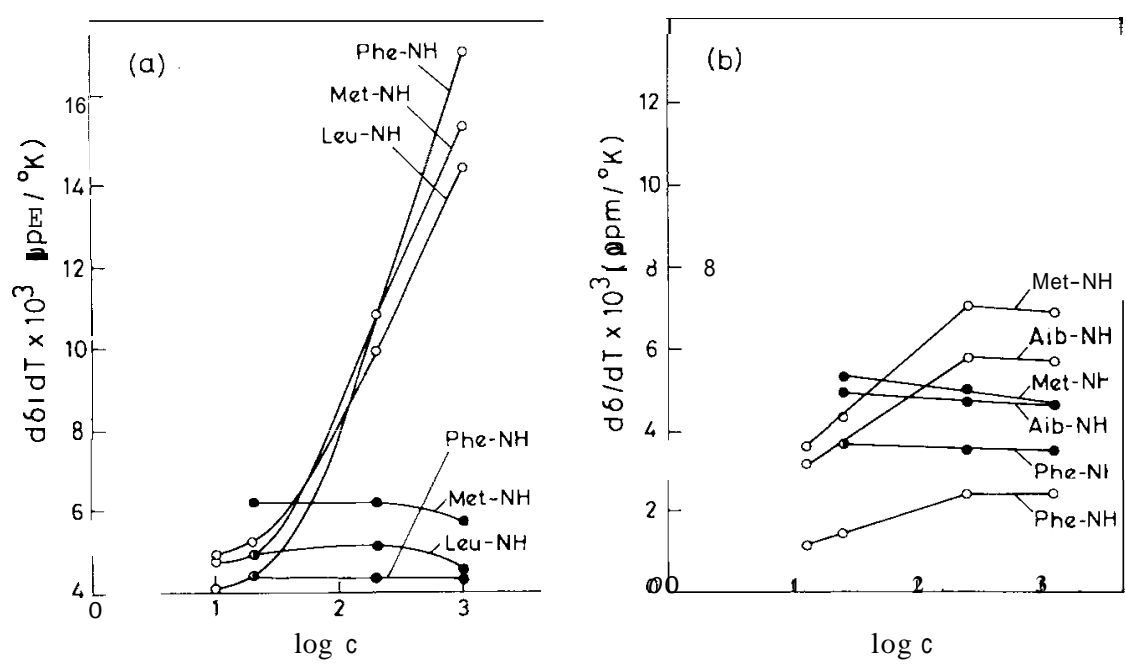

Fig. 3. Concentration dependence of temperature coefficients $(d \delta / d T)$ of NH resonances. (a) For-Met-Leu-Phe-OMe (1): $\left(\mathrm{CD}_{3}\right)_{2} \mathrm{SO} ; \mathrm{O}, \mathrm{CDCl}_{3}$. (b) For-Met-Aib-Phe-OMe (2):,$\left(\mathrm{CD}_{3}\right)_{2} \mathrm{SO} ; \mathrm{O}, \mathrm{CDCl}_{3}$. Abscissa expresses concentration as log $\boldsymbol{C}$, as in Fig. 1 . 
sharply downfield at concentrations $>1 \mathrm{~m} M$. The $\mathrm{C}^{\alpha} \mathrm{H}$ resonances of Met and Leu move slightly downfield at higher concentrations, while the $\mathrm{Phe} \mathrm{C}^{\alpha} \mathrm{H}$ peak is insensitive. The $d \delta / d T$ values for all $\mathrm{NH}$ groups in 1 are strongly concentration dependent in $\mathrm{CDCl}_{3}$ (Fig. 3). The data clearly suggest that peptide association of $\mathbf{1}$ is significant in $\mathrm{CDCl}_{3}$ at concentrations $\gtrsim 1 \mathrm{~m} M$. In peptide 2 , the concentration dependence of 6 values differentiates the various $\mathrm{NH}$ groups. While the Phe $\mathrm{NH}$ shows a small but linear downfield shift with increasing concentration, the Aib and Met NH groups show a sharp discontinuity at $\sim 2.4 \mathrm{mM}$. No concentration dependence is observed for the $\mathbf{6}$ values of the formyl (HCO) and $\mathrm{C}^{a} \mathrm{H}$ resonance. Thus, it appears that the Aib and Met $\mathrm{NH}$ groups are exposed and, at higher concentrations, participate in intermolecular hydrogen bonding. There is no convincing evidence for the involvement of the Phe NH in peptide association. Furthermore, at concentrations $<2.4 \mathrm{~m} M, 2$ appears to be in an unaggregated state in $\mathrm{CDCl}_{3}$, since the $\mathbf{6}$ versus concentration curves are flat in this region.

The $d \delta / d T$ values for the $\mathrm{NH}$ groups in 2 , in $\mathrm{CDCl}_{3}$, show a pronounced concentration dependence, increasing with peptide concentration (Fig. 3). Low $d \Delta / d T$ values in $\mathrm{CDCl}_{3}(<0.0024 \mathrm{ppm} / \mathrm{K})$ may be attributed to solvent-exposed or -shielded $\mathrm{NH}$ groups, while high $d \delta /$ $d T$ values $(>\mathbf{0 . 0 0 3 5} \mathrm{ppm} / \mathrm{K})$ are characteristic of NH groups involved in intermolecular hydrogen bonding. ${ }^{4-6}$ The results suggest that Met and Aib NH groups are involved in peptide association, while $\mathrm{Phe} \mathrm{NH}$ does not appear to participate in a significant intermolecular interaction. Phe $\mathrm{NH}$ has an extremely low $d \delta / d T$ value in $\mathrm{CDCl}_{3}$ at 2.4 $\mathrm{m} M$ but does show an increase at higher concentrations. This may be indicative of its participation in a weak intramolecular hydrogen bond, with the population of such species decreasing on heating. Further support for this conclusion is derived from paramagnetic radicalinduced broadening of $\mathrm{NH}$ resonances in $\mathrm{CDCl}_{3},{ }^{21}$ as well as from solvent-titration experiments. ${ }^{22}$ Addition of the free radical, 2,2,6,6tetramethylpiperidine-1-oxyl (TEMPO), causes almost equal line broadening of all three NH groups in the case of peptide 1 [Fig. 4(a)]. However, in peptide 2 [Fig. 4(b)], the Aib and Met $\mathrm{NH}$ groups are significantly more affected than Phe $\mathrm{NH}$, suggesting that the latter is indeed, shielded from the solvent. The formyl proton resonance is unaffected by TEMPO addition and serves as an internal control. The dependence of $\mathrm{NH}$ chemical shifts on $\left(\mathrm{CD}_{3}\right)_{2} \mathrm{SO}$ Concentration in $\mathrm{CDCl}_{3}-$ $\left(\mathrm{CD}_{3}\right)_{2} \mathrm{SO}$ mixtures in 1 and 2 are presented in Fig. 5. While all three $\mathrm{NH}$ groups in $\mathbf{1}$ show a pronounced solvent dependence, in $\mathbf{2}$ the Phe $\mathrm{NH}$ is markedly less sensitive to the addition of the strongly hydrogenbond-accepting component. Peptide 1 should have been significantly associated under the conditions of the TEMPO broadening experiment, while aggregation effects may be less important for $\mathbf{2}$. In peptide $\mathbf{2}$, the $\boldsymbol{d} \delta / d T$ values measured in $\left(\mathrm{CD}_{3}\right)_{2} \mathrm{SO}$ are concentration independent. However, the Phe $\mathrm{NH}$ resonance does have a relatively low $d \delta$ / 

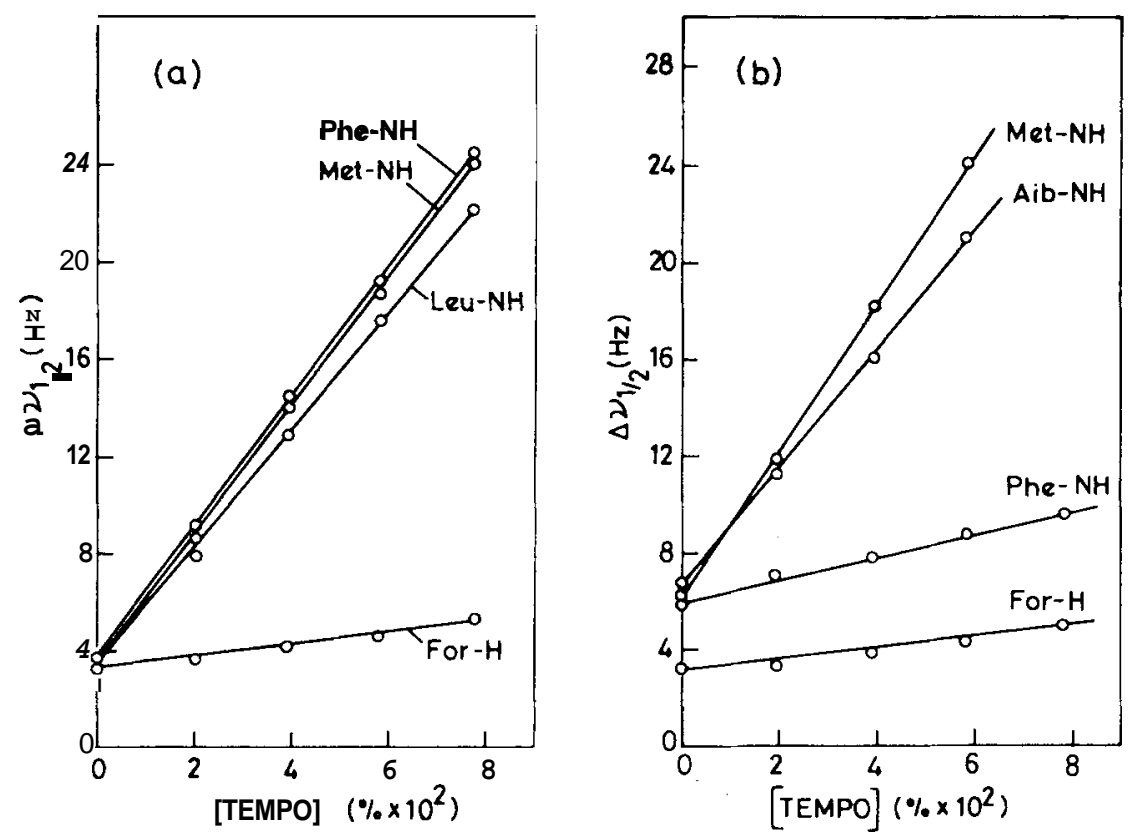

Fig. 4. Effect of increasing concentration of the free radical, TEMPO, on the linewidths of the NH and formyl proton resonances. TEMPO concentrations range from $\sim 0.02$ to $0.08 \%$. (a) For-Met-Leu-Phe-OMe (1), (b) For-Met-Aib-Phe-OMe (2). Peptide concentration, $\sim 11 \mathrm{mM}$; solvent, $\mathrm{CDCl}_{3}$.

$d T$ value $(\sim 0.0035 \mathrm{ppm} / \mathrm{K})$, which argues for at least a partial shielding of this NH group from the solvent. NH groups that are relatively strongly hydrogen bonded (solvent shielded) have $\mathrm{d} \delta / d T$ values $<0.003 \mathrm{ppm} / \mathrm{K}$, while solventexposed groups are generally charac-
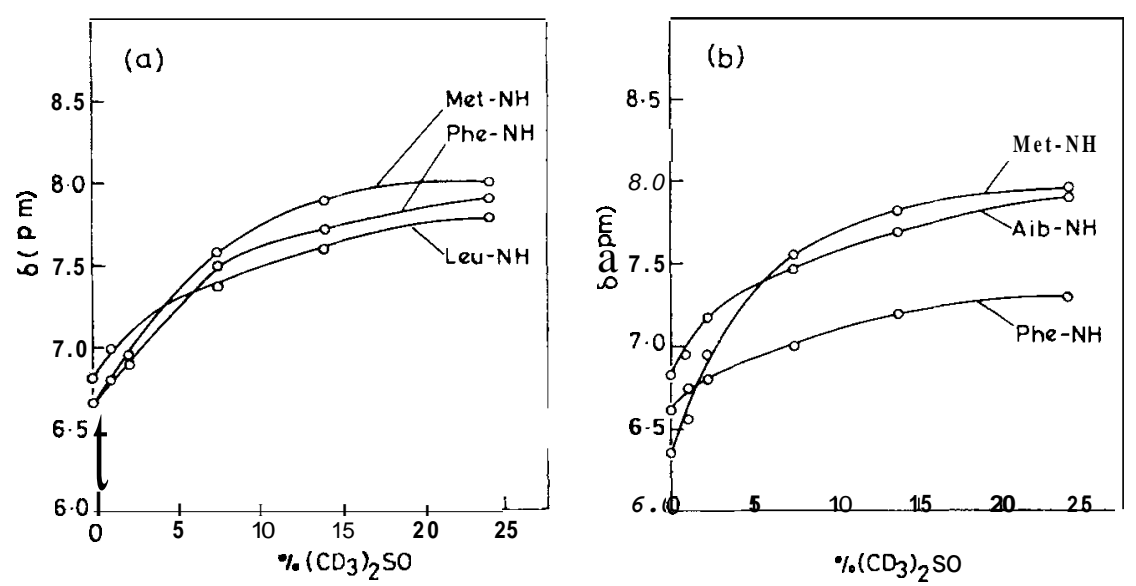

Fig. 5. Dependence of $\mathrm{NH}$ chemical chifta on $\left(\mathrm{CD}_{3}\right)_{2} \mathrm{SO}$ concentration in mixtures of $\mathrm{CDCl}_{3}$ and $\left(\mathrm{CD}_{3}\right)_{2} \mathrm{SO}$. Peptide concentration -11 mM. (a) For-Met-Leu-Phe-OMe (1), (b) For-Met-Aib-Phe-OMe (2). 
terized by $d \delta / d T>0.004 \mathrm{ppm} / \mathrm{K}$, in $\left(\mathrm{CD}_{3}\right)_{2} \mathrm{SO} .5,23,24$ Values between 0.003 and $0.004 \mathrm{ppm} / \mathrm{K}$ are difficult to interpret with certainty, although they have been frequently assigned to weakly hydrogen-bonded NH groups. 25,26

The above results suggest that For-Met-Leu-Phe-OMe aggregates in $\mathrm{CDCl}_{3}$. The results are consistent with the formation of $\beta$-sheet aggregates, both "in-register" and "out-register" (Fig. 6) as proposed for oligopeptides of norvaline. ${ }^{1}$ In $\left(\mathrm{CD}_{3}\right)_{2} \mathrm{SO}$ there is no evidence for folded intramolecularly hydrogen-bonded conformations. Extended structures, as proposed for the free acid, ${ }^{12}$ are consistent with the $\mathrm{nmr}$ results. In For-Met-Aib-Phe-OMe (2), the Phe NH is partially shielded from the solvent and presumably intramolecularly hydrogen-bonded in $\mathrm{CDCl}_{3}$ and $\left(\mathrm{CD}_{3}\right)_{2} \mathrm{SO}$. The Aib and Met $\mathrm{NH}$ groups are solvent-ex-

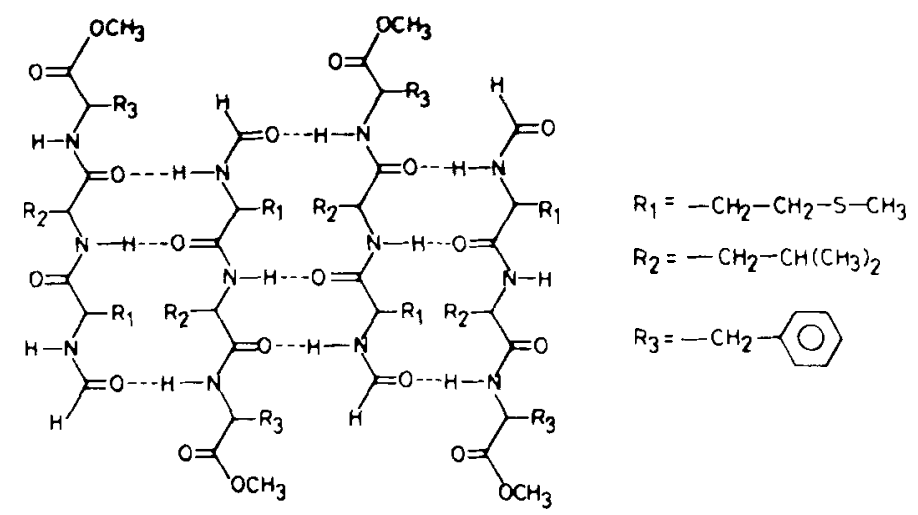

(a)

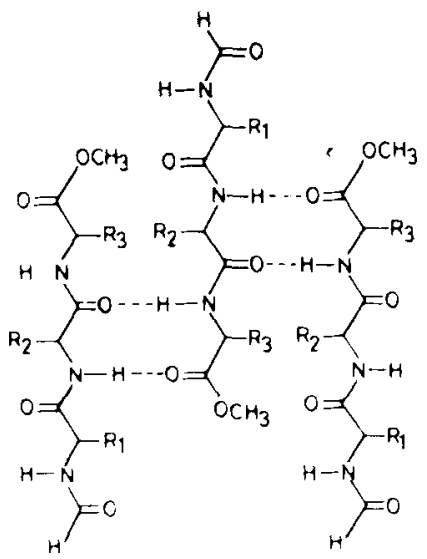

(b)

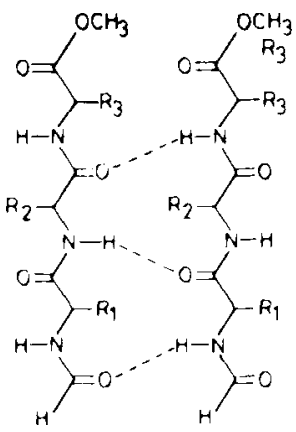

(c)

Fig. 6. Schematic representation of aggregation modes For For-Met-Leu-PheOMe (1) in chloroform: (a) antiparallel $\beta$-sheets "in register," (b) antiparallel $\beta$-sheets "out of register," and (c) parallel $\beta$-sheet aggregates. 
posed and form intermolecular hydrogen bonds at high peptide concentrations in $\mathrm{CDCl}_{3}$. The involvement of the $\mathrm{Phe} \mathrm{NH}$ in intramolecular hydrogen bonding favors a folded conformation for 2 . Two possible conformations are illustrated in Fig. 7. The $\beta$-turn structure [Fig. 7(a)] involves a $4 \rightarrow \mathbf{1}$ hydrogen bond between the formyl $\mathrm{CO}$ group and Phe $\mathrm{NH}$, while the y-turn conformation [Fig. 7(b)] is stabilized by a $3 \rightarrow 1$ hydrogen bond between Met $\mathrm{CO}$ and Phe NH.27,28 [The y-turn is defined as a structure involving a single $3 \rightarrow \mathbf{1}\left(\mathrm{C}_{7}\right)$ hydrogen bond, as suggested in Ref. 27.1 The $\beta$-turn structure, with Aib as the $i+2$ residue, has been crystallographically observed in a large number of Aib-containing peptides. ${ }^{13-16}$ The y-turn $\left(\mathrm{C}_{7}\right)$ conformation has been observed in the crystal structure of the cyclic tetrapeptide, dihydrochlamydocin, ${ }^{29}$ and has been suggested on the basis of ir studies of several Aib-containing dipeptides. ${ }^{30-32}$ In general, $\beta$-turn structures, with backbone conformational angles of $\phi \sim \pm 60^{\prime \prime} \pm 20 "$ and $\psi \sim \pm 20^{\prime \prime} \pm 20^{\circ}$, are favored for the Aib residue. ${ }^{13-16}$ The y-turn ( $\left.\phi \sim \pm 70^{\circ}, \psi \sim \pm 70^{\prime \prime}\right)$ is less frequently observed. The moderately high value of $d \delta / d T(0.0035) \mathrm{ppm} / \mathrm{K})$ observed for $\mathrm{Phe} \mathrm{NH}$ in $\left(\mathrm{CD}_{3}\right)_{2} \mathrm{SO}$, and the concentration dependence of $d \delta / d T$ in $\mathrm{CDCl}_{3}$ suggest a relatively weak hydrogen bond. However, $\beta$-turn structures in Aib peptides have been generally characterized by strong intramolecular hydrogen bonds, as evidenced by low $d \delta / d T$ values in $\left(\mathrm{CD}_{3}\right)_{2} \mathrm{SO} \cdot{ }^{19,20,25,26,33-36}$ The $\beta$-and $y$-turn structures are distinguishable if the identity of the hydrogen-bonded carbonyl group can be determined.

\section{${ }^{13}$ C-NMR Studies}

The $67.89-\mathrm{MHz}{ }^{13} \mathrm{C}-\mathrm{nmr}$ spectra of peptides 1 and 2 showed four carbonly carbon resonances between 160 and $175 \delta$. The chemical shifts $(\delta)$ in $\mathrm{CHCl}_{3}$ and $\mathrm{CH}_{3} \mathrm{OH}$ solutions are listed in Table I. A solventtitration experiment, ${ }^{37,38}$ carried out in $\mathrm{CHCl}_{3}-\mathrm{CH}_{3} \mathrm{OH}$ mixtures of varying composition, confirmed the absence of any crossover of peaks

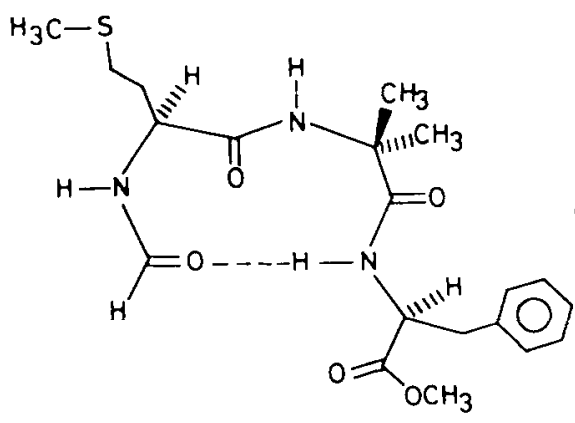

(a)

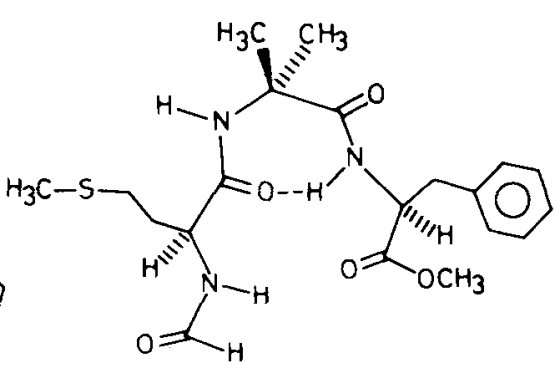

(b)

Fig. 7. Possible folded conformations of For-Met-Aib-Phe-OMe (2): (a) $\beta$-turn, (b) $\gamma$ turn $\left(\mathrm{C}_{7}\right)$. 
TABLE I

${ }^{23} \mathrm{C}$ Chemical Shifts ${ }^{a}$ of Carbonyl Carbons in Peptides 1 and 2

\begin{tabular}{|c|c|c|c|c|c|c|c|}
\hline \multirow[b]{2}{*}{ Carbonyl } & \multicolumn{3}{|c|}{$1^{b}$} & \multirow[b]{2}{*}{ Carbonyl } & \multicolumn{3}{|c|}{$2^{c}$} \\
\hline & $\mathrm{CDCl}_{3}$ & $\mathrm{MeOH}$ & A6 & & $\mathrm{CDCl}_{3}$ & $\mathrm{MeOH}$ & A6 \\
\hline $\mathrm{CO}(1)$ & 171.9 & 174.3 & 2.4 & $\mathrm{CO}(1) \mathrm{Aib}$ & 173.6 & 176.4 & 2.8 \\
\hline $\mathrm{CO}(2)$ & 171.7 & 173.8 & 2.1 & $\mathrm{CO}(2) \mathrm{Met}$ & 172.1 & 173.5 & 1.4 \\
\hline $\mathrm{CO}(3)$ & 171.0 & 173.2 & 2.2 & CO(3) Phe & 170.3 & 172.7 & 2.4 \\
\hline CO(4) (Formyl) & 161.1 & 163.7 & 2.6 & $\mathrm{CO}(4)$ (Formyl) & 161.2 & 163.9 & 2.7 \\
\hline
\end{tabular}

a Peptide concentration, $\sim 0.09 \mathrm{M}$.

b Specific assignments have not been made.

c Assignments made as described in the text.

on going to the more strongly hydrogen-bonding donor solvent, $\mathrm{CH}_{3} \mathrm{OH}$ (peptide concentration $\sim 0.09 M$ ). The formyl ( $\mathrm{HCO}$-) peak is easily assigned to the high-field resonance at $161-164 \delta$ by virtue of its appearance as a doublet in the ${ }^{1} \mathrm{H}$ - off-resonance-decoupled ${ }^{13} \mathrm{C}$ spectrum. In peptide 2, the Aib CO group is assigned to the low-field resonance $[\mathrm{CO}(1)]$, as comparisons with a number of related peptides establishes a downfield shift of the $\mathrm{CO}$ resonance on a-alkylation. The Met and Phe CO groups were assigned by comparison of the shifts in the peptides, For-Met-Leu-Phe-OH and For-Met-Leu-Phe- $\mathrm{NH}_{2}$ (data not shown). The Phe $\mathrm{CO}$ shows small but significant shifts between the ester, acid, and amide derivatives. A similar assignment of the $\mathrm{CO}$ resonances in $\mathbf{1}$ was not possible. However, the data in Table I show that all the $\mathrm{CO}$ groups in 1 experience a similar downfield shift $(-2.1$ to $2.6 \mathrm{ppm}$ ) on going from $\mathrm{CHCl}_{3}$ to $\mathrm{CH}_{3} \mathrm{OH}$, suggesting almost equal degrees of exposure to solvent. A specific assignment is therefore unimportant for conformational arguments. On the contrary, in 2, the Met CO group experiences a substantially smaller downfield shift, suggesting its relative inaccessibility to solvent. ${ }^{37,38}$ The similarity of the solvent shifts for the formyl $\mathrm{CO}$ in $\mathbf{1}$ and $\mathbf{2}$ suggests that this group is exposed (not hydrogen-bonded) in both peptides. This observation strongly argues against the $\beta$-turn conformation [Fig. 7(a)] as a preferred structure for 2 . The ${ }^{13} \mathrm{C}$ results thus suggest that a y-turn $\left(\mathrm{C}_{7}\right)$ conformation involving a $3 \rightarrow 1$ hydrogen bond (Met CO---HN Phe) is consistent with both ${ }^{1} \mathrm{H}$ - and ${ }^{13} \mathrm{C}-\mathrm{nm} r$ data.

The ${ }^{13} \mathrm{C}$ chemical shifts of the $\mathrm{CO}$ carbons in 2 show a monotonic downfield shift with increasing $\mathrm{CH}_{3} \mathrm{OH}$ concentration in $\mathrm{CHCl}_{3}$ $\mathrm{CH}_{3} \mathrm{OH}$ mixtures. The absence of discontinuous chemical-shift changes argues against solvent-induced conformational transitions.

\section{IR Studies}

Figure 8 shows the NH stretching region of the ir spectra of $\mathbf{1}$ and 2 in $\mathrm{CHCl}_{3}$ solutions over the concentration range of $1.6-50 \mathrm{mM}$. At high concentrations of $\mathbf{1}$, two bands are observed at -3320 and -3430 

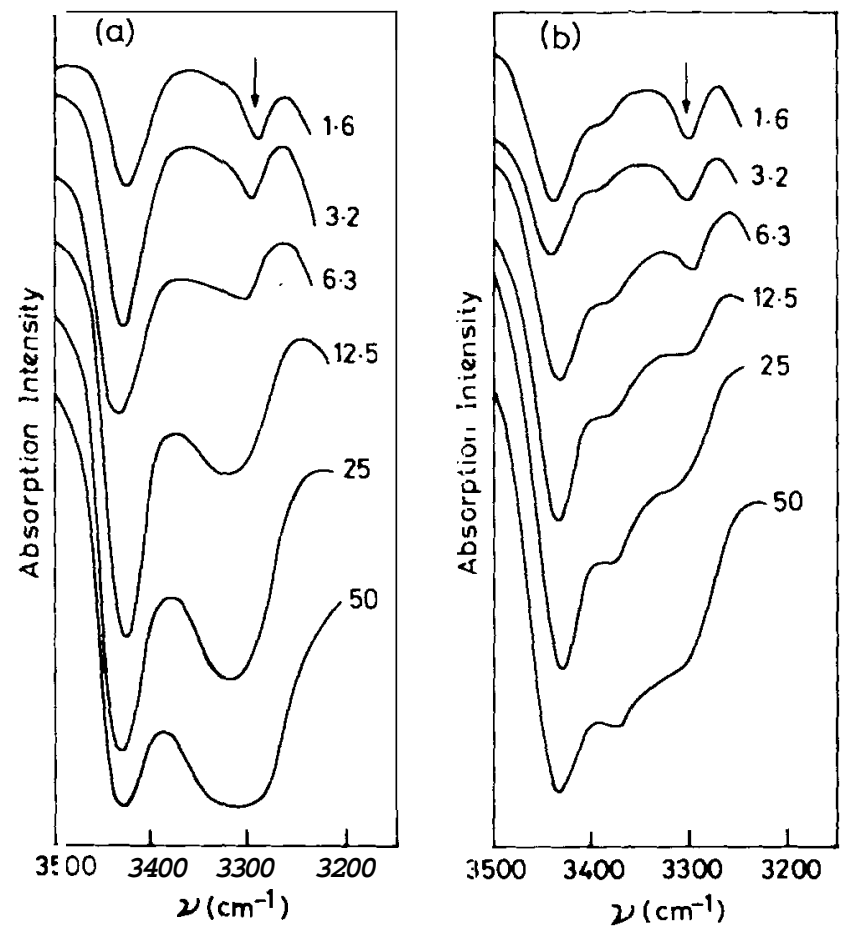

Fig. 8. The ir spectra (NH stretching bands) in $\mathrm{CHCl}_{3}$ at various peptide concentrations indicated against the traces: (a) For-Met-Leu-Phe-OMe (1), (b) For-Met-Aib-Phe$\mathrm{OMe}\{2$ ). The arrow marks the position of the solvent absorption band.

$\mathrm{cm}-{ }^{1}$, corresponding to hydrogen-bonded $\left[\nu_{\mathrm{NH}}(\mathrm{hb})\right]$ and free $\left[\nu_{\mathrm{NH}}(f)\right] \mathrm{NH}$ groups, respectively. ${ }^{30-32}$ The $v_{\mathrm{NH}}(\mathrm{hb})$ peak disappears at concentrations $<6 \mathrm{~m} M$, suggesting that peptide 1 exists as unassociated species below this concentration in $\mathrm{CHCl}_{3}$. Furthermore, there is no evidence for formation of an intramolecular hydrogen bond, supporting the conclusions of the nmr studies. In peptide 2 , the appearance of the $\mathrm{NH}$ bands is significantly different from the case of $\mathbf{1}$. At equivalent concentrations, the intensities of the 3320-cm-' band is less in 2 when compared with 1. Further, a third NH stretching peak is observed at $3385 \mathrm{~cm}^{-1}$. While the $3320-\mathrm{cm}^{-1}$ peak disappears at low concentrations ( $<10 \mathrm{mM}$ ), the $3385-\mathrm{cm}^{-1}$ band is largely concentration-independent and is observed even at $1.6 \mathrm{~m} M$. This band may therefore be assigned to an intramolecularly hydrogen-bonded NH group. A plot of the ratio, $\nu_{\mathrm{NH}}(\mathrm{hb}) / \nu_{\mathrm{NH}}(\mathrm{f})\left[\nu_{\mathrm{NH}}(\mathrm{hb})=3320 \mathrm{~cm}^{-1}\right]$. shows a steep concentration dependence above $2 \mathrm{mM}$ in the case of $\mathbf{1}$. No such dependence is observed for 2 (not shown). Figure 9 shows the NH-absorption bands in the ir spectra of $\mathbf{1}$ and $\mathbf{2}$ for the solid state. In 1, only a single band is observed at $-3290 \mathrm{~cm}^{-1}$, suggesting that all $\mathrm{NH}$ groups are involved in intermolecular hydrogen bonding. In contrast, 2 exhibits a shoulder at 

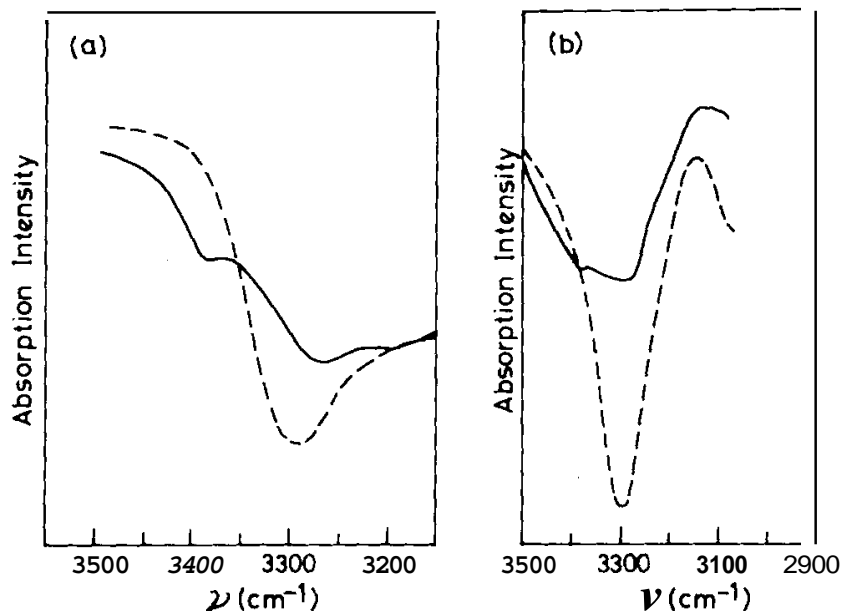

Fig. 9. NH stretching bands in the ir spectra of peptides in the aggregated state for (a) Nujol mull and (b) KBr pellet: - . , For-Met-Leu-Phe-OMe (1); -, For-Met-Aib-PheOMe (2).

3385-3390 $\mathrm{cm}^{-1}$, in addition to the low-frequency $\nu_{\mathrm{NH}}(\mathrm{hb})$ peak at $-3290 \mathrm{~cm}^{-1}$ in both nujol mull and $\mathrm{KBr}$ pellet spectra. The ir results suggest that 2 adopts a folded conformation in solution, stabilized by an intramolecular hydrogen bond and that this interaction is maintained in the solid state. The position of the intramolecularly hydrogenbonded $\nu_{\mathrm{NH}}$ peak at $3385 \mathrm{~cm}^{-}$' suggests a relatively weak $\mathrm{H}-\mathrm{H}$ - - - O interaction, consistent with a y-turn $\left(\mathrm{C}_{7}\right)$ conformation. ${ }^{30-32,39,40}$ In earlier studies of Aib-containing peptides, it has been observed that the stronger $\mathbf{4} \rightarrow \mathbf{1}\left(\mathrm{C}_{10}\right)$ interaction is characterized by a $\boldsymbol{\nu}_{\mathrm{NH}}$ band at lower frequency $\left(-3340 \mathrm{~cm}^{-1}\right){ }^{30-32} \nu_{\mathrm{NH}}$ bands at $3380-3400 \mathrm{~cm}^{-1}$ have often been assigned to $\mathrm{C}_{7}$ structures. ${ }^{30,31,39,40}$ It should, however, be noted that a range of strengths is possible for $\beta$-turn hydrogen bonds. The ir data alone cannot, therefore, be used to argue for a $\mathrm{C}_{7}$ structure, but in conjuction with the ${ }^{13} \mathrm{C}-\mathrm{nmr}$ data, there is reasonable circumstantial evidence in favor of a y-turn conformation.

\section{Studies}

There has been only a single report of a CD study of the parent chemotactic peptide, For-Met-Leu-Phe-OH in the solvents trifluoroethanol (TFE) and $96.4 \% \mathrm{H}_{2} \mathrm{SO}_{4}$. This suggested the possibility of folded conformational states. ${ }^{41}$ Figure 10 shows the CD spectra of peptides $\mathbf{1}$, 2, For-Met-Leu-Leu-OMe (3), and For-Met-Aib-Leu-OMe (4) in various solvent systems. The CD parameters are summarized in Table 11.Peptides 3 and 4 were examined in order to evaluate the extent of Phe side-chain contribution to the observed CD bands. ${ }^{42}$ Peptides 1 and 3 exhibit a negative band at $-227-235 \mathrm{~nm}$ and a positive one at 210 $217 \mathrm{~nm}$ in methanol, dioxane, and TFE. The positive and negative 

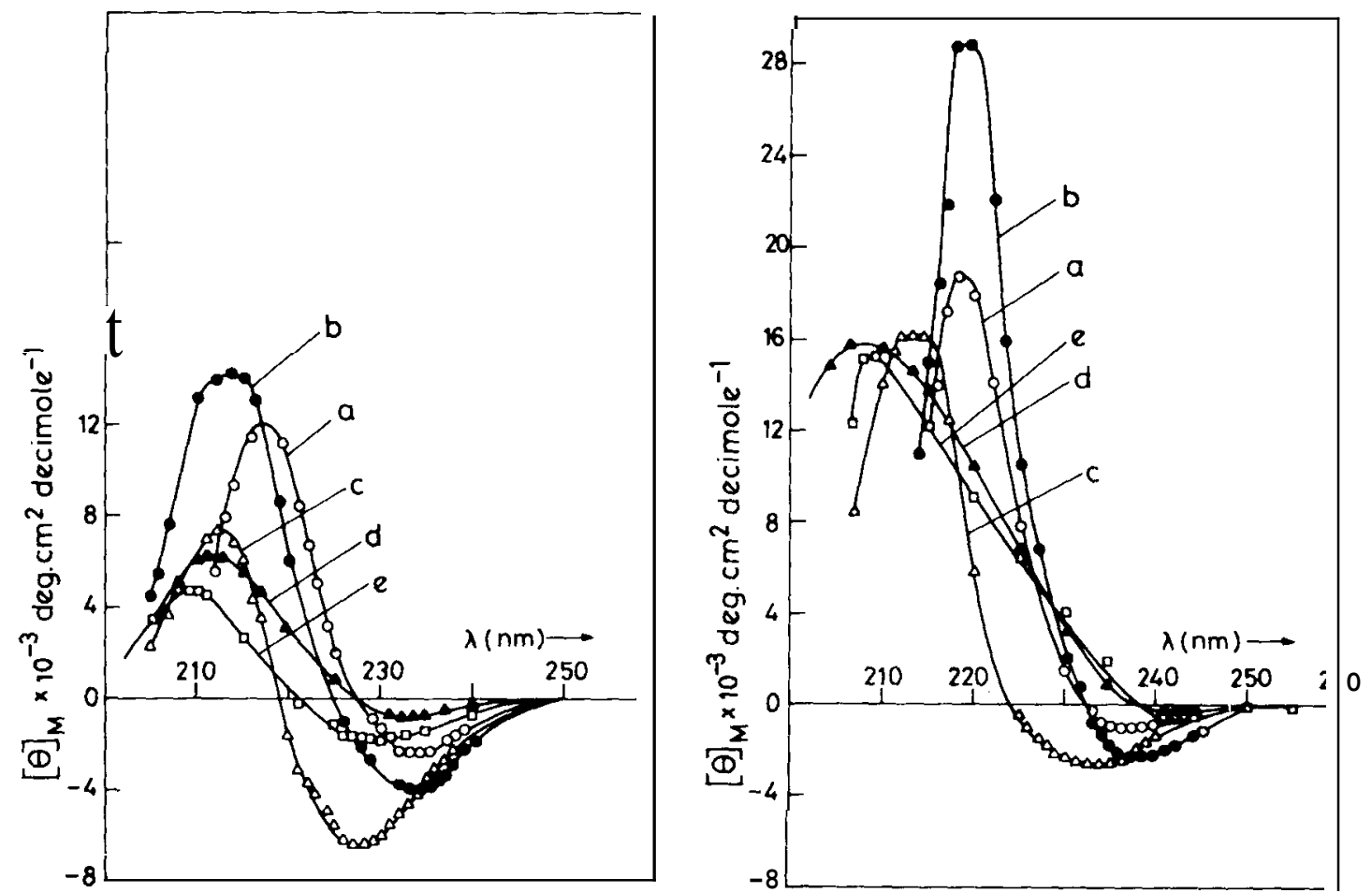

Fig. 10. CD spectra of peptides in various solvents. (Left) For-Met-Leu-Phe-OMe (1) in (a) MeOH, (b) dioxane, (c) TFE; For-Met-Leu-Leu-OMe (3) in (d) MeOH and (e) dioxane. (Right) For-Met-AibPhe-OMe (2) in (a) MeOH, (b) dioxane, (c) TFE; For-Met-AibLeu-OMe (4) in (d) MeOH and (e) dioxane. Peptide concentration, $-2.2 \mathrm{mM}$. 
TABLE II

CD Parameters' for Peptides 1 and 2

\begin{tabular}{|c|c|c|c|c|c|c|c|c|}
\hline \multirow[b]{2}{*}{ Solvent $\mathrm{t}^{\mathrm{b}}$} & \multicolumn{4}{|c|}{1} & \multicolumn{4}{|c|}{2} \\
\hline & $\underset{(\mathrm{nm})}{\lambda}$ & $M$ & $\begin{array}{c}h \\
(\mathrm{~nm})\end{array}$ & {$[\theta]_{M}$} & $\underset{(\mathrm{nm})}{\lambda}$ & {$[\theta]_{M}$} & $\begin{array}{c}h \\
(\mathrm{~nm})\end{array}$ & {$[\theta]_{M}$} \\
\hline $\mathrm{MeOH}$ & 217 & +12100 & 233 & -2500 & 218.5 & +18600 & 238 & -1000 \\
\hline Dioxane & 214 & +14400 & 233 & -4100 & 218.5 & +26800 & 238 & -2300 \\
\hline TFE & 212 & +7500 & 228 & -6200 & 213 & +16200 & 233 & -2600 \\
\hline \multicolumn{9}{|l|}{ Dioxane-water (v/v) } \\
\hline $1: 1$ & 217 & +9400 & 232 & -2500 & 216 & +14400 & 238 & -300 \\
\hline $1: 3$ & 217 & +7200 & 232 & -2200 & 217 & +14200 & 239 & -300 \\
\hline $3: 1$ & 216 & +10400 & 232 & -2900 & 216 & +14600 & 238 & -800 \\
\hline Dioxane cyclohexane, $1: 1(\mathrm{v} / \mathrm{v})$ & 214 & +14400 & 233 & -4100 & 218 & +16500 & 238 & -900 \\
\hline \multicolumn{9}{|l|}{$\mathrm{MeOH}-$ water (v/v) } \\
\hline $1: 1$ & 217 & +6600 & 231 & -2400 & 217 & +20700 & 237 & -1300 \\
\hline $1: 3$ & 216 & +7800 & 232 & -2600 & 215 & +15100 & 237 & -500 \\
\hline
\end{tabular}

${ }^{a}[\theta]_{M}$ is molar ellipticity expressed as $\mathrm{deg} \mathrm{cm} \mathrm{cmol}^{-1}$.

${ }^{\mathrm{b}}$ The peptide concentration in all cases is $1 \mathrm{mg} / \mathrm{mL}(-2.2 \mathrm{mM})$. 


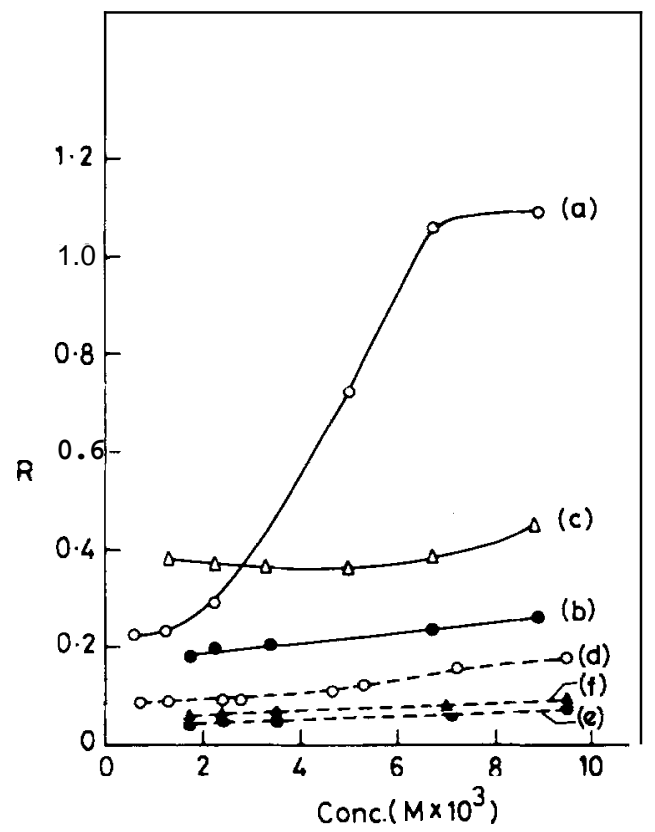

Fig. 11. Dependence of the ratio of CD band intensities $\left(R=[\theta]_{n-\pi^{*}} /[\theta]_{\pi-\pi^{*}}\right)$ on peptide concentration. For-Met-Leu-Phe-OMe (1) in (a) dioxane, (b) MeOH, (c) 1:1 (v/v) $\mathrm{MeOH}-\mathrm{H}_{2} \mathrm{O}$; For-Met-Aib-Phe-OMe (2) in (d) dioxane, (e) $\mathrm{MeOH}$, (f) $1: 1$ (v/v) $\mathrm{MeOH}-$ $\mathrm{H}_{2} \mathrm{O} .[\theta]_{\pi-\pi}$ ranges from $214-223 \mathrm{~nm}$ and $[\theta]_{n-\pi} *$ from $231-240 \mathrm{~nm}$.

bands are significantly weaker in peptide $\mathbf{3}$, which lacks the Phe residue. While an altered backbone conformation cannot be ruled out, this observation suggests that aromatic side-chain contributions to the observed Cotton effect may be substantial. Qualitatively similar CD spectra are observed for peptide 2, and the differences in the spectra of 2 and 4 (Fig. 10) again suggest Phe side-chain contributions. While definitive conformational conclusions cannot be safely drawn from the $\mathrm{CD}$ data, it is possible to probe aggregation effects. Dioxane was chosen as a solvent in view of its transparency in the 200-250-nm region and its relatively poor solvating (hydrogen-bonding) power, which should promote molecular association. $\mathrm{CH}_{3} \mathrm{OH}$ and $\mathrm{CH}_{3} \mathrm{OH}-\mathrm{H}_{2} \mathrm{O}$ mixtures were also studied for comparison. Figure 11 shows the dependence of the ratio of the two CD bands on concentration for peptides $\mathbf{1}$ and $\mathbf{2}$. A dramatic solvent dependence is observed for $\mathbf{1}$ in dioxane, whereas no effect is seen for $\mathbf{2}$. The data suggest that $\mathbf{1}$ aggregates in dioxane at concentrations $>\mathbf{3} \mathrm{m} M$. No concentration effects are detectable for both peptides in methanol and methanol-water mixtures.

\section{CONCLUSIONS}

1.For-Met-Leu-Phe-OMe (1)and For-Met-Aib-Phe-OMe (2) aggregate in solvents of low polarity such as chloroform at concentrations $>2$ $\mathrm{m} M$. Aggregation effects are more pronounced for $\mathbf{1}$. 
2. Both peptides appear to be unassociated in strongly polar, hydrogen-bonding solvents like dimethylsulfoxide and methanol. This behavior is concentration independent.

3. The concentration dependence of the spectroscopic data suggests that aggregation is a more facile process in an extended peptide conformation as exemplified by $\mathbf{1}$, as compared with a folded peptide exemplified by 2.

4. Peptide 1 favors nonintramolecularly hydrogen-bonded, presumably extended conformations in both low-polarity solvents and in polar solvents. The spectral data for 2 in chloroform and dimethylsulfoxide are consistent with a significant population of folded peptide conformations. A y-turn $\left(\mathrm{C}_{7}\right)$ conformation stabilized by a $\mathbf{3} \rightarrow \mathbf{1}$ hydrogen bond between the Met $\mathrm{CO}$ and Phe NH groups is compatible with the reported spectroscopic results.

This research was supported by a grant from the Department of Science and Technology, Government of India. P.A.R. acknowledges the receipt of a Teacher-Fellowship of the University Grants Commission.

\section{References}

1. Pysh, E. S. \& Toniolo, C. (1977)J. Am. Chem. Soc. 99, 6211-6219.

2. Meraldi, J. P. \& Hruby, V. J. (1976) J. Am. Chem. Soc. 98, 6408-6410.

3. Higashijima, T., Tasumi, M., Miyazawa, T. \& Miyoshi, M. (1978) Eur. J. Biochem. 89, 543-556.

4. Iqbal, M. \& Balaram, P. (1981) Biochemistry 20, 7278-7284.

5. Iqbal, M. \& Balaram, P. (1982) Biopolymers 21, 1427-1433.

6. Stevens, E. S., Sugawara, N., Bonora, G. M. \& Toniolo, C. (1980)J. Am. Chem. Soc. 102, 7408-7050.

7. Sugawara, N., Stevens, E. S., Bonora, G .M. \& Toniolo, C. (1980)J. Am. Chem. Soc. 102, 7044-7047.

8. Wilkening, R. R., Stevens, E. S., Bonora, G. M. \& Toniolo, C. (1983) J. Am. Chem. Soc. 105, 2560-2561.

9. Showell, H. J., Freer, R. J., Zigmond, S. H., Schiffmann, E., Aswanikumar, S., Corcoran, B. \& Becker, E. L. (1976) J. Exp. Med. 143, 1154-1169.

10. Freer, R. J., Day, A. R., Radding, J. A., Schiffmann, E., Aswanikumar, S., Showell, H. J. \& Becker, E. L. (1980) Biochemistry 19, 2404-2410.

11. Schiffmann, E., Corcoran, B. A. \& Wahl, S. M. (1975) Proc. Natl. Acad. Sci. USA 72, 1059-1062.

12. Becker, E. L., Bleich, H. E., Day, A. R., Freer, R. J., Glasel, J. A. \& Visintainer, J. (1979) Biochemistry 18, 4656-4668.

13. Nagaraj, R. \& Balaram, P. (1981) Acc. Chem. Res. 14, 356-362.

14. Prasad, B. V. V. \& Balaram, P. (1982) Conformation in Biology, Srinivasan, R., Sarma, R. H., Eds., Adenine Press, New York, pp. 133-139.

15. Prasad, B. V. V. \& Balaram, P. (1984) CRC Crit. Rev. Biochem. 16, 307-348.

16. Toniolo, C., Bonora, G. M., Bavoso, A., Benedetti, C., DiBlasio, B., Pavone, V. \& Pedone, C. (1983) Biopolymers 22, 205-215.

17. Iqbal, M., Balaram, P., Showell, H. J., Freer, R. J. \& Becker, E. L. (1984) FEBS Lett. 165, 171-174.

18. Nagaraj, R. \& Balaram, P. (1981) Tetrahedron 37, 1263-1270.

19. Nagaraj, R. \& Balaram, P. (1981) Biochemistry 20, 2828-2835.

20. Iqbal, M. \& Balaram, P. (1981) J. Am. Chem. Soc. 103, 5548-5552.

21. Kopple, K. D., GO, A. \& Pilipauskas, D. R. (1975) J. Am. Chem. Soc. 97, 6830-6838. 
22. Pitner, T. P.\& Urry, D. W. (1972) J. Am. Chem. Soc. 94, 1399-1400.

23. Hruby, V. J. (1974) Chemistry and Biochemistry of Amino Acids, Peptides and Proteins, Vol. 3, Weinstein, B., Ed., Dekker, New York, pp. 1-188.

24. Venkatachalapathi, Y. V. \& Balaram, P. (1981) Biopolymers 20, 625-628.

25. Ravi, A., Prasad, B. V. V. \& Balaram, P. (1983) J. Am. Chem. Soc. 105, 105-109.

26. Vijayakumar, E. K. S. \& Balaram, P. (1983) Tetrahedron 39, 2725-2731.

27. Smith, J. A. \& Pease, L. G. (1980) CRC Crit. Reu. Biochem. 8, 315-399.

28. Toniolo, C. (1980) CRC Crit. Rev. Biochem. 9, 144.

29. Flippen, J. L. \& Karle, I. L. (1976) Biopolymers 15, 1081-1092.

30. Aubry, A., Protas, J., Boussard, G., Marraud, M. \& Neel, J. (1978) Biopolymers 17, 1693-1712. 431 .

32. Benedetti, E., Bavoso, A., DiBlasio, B., Pavone, V., Pedone, C., Crisma, M., Bonora, G. M. \& Toniolo, C. (1982) J. Am. Chem. Soc. 104, 2437-2444.

33. Venkatachalapathi, Y. V., Nair, C. M. K., Vijayan, M. \& Balaram, P. (1981) Biopolymers 20, 1123-1136.

34. Prasad, B. V. V., Balaram, H. \& Balaram, P. (1982) Biopolymers 21, 1261-1273.

35. Iqbal, M., Nagaraj, R. \& Balaram, P. (1981) Int. J. Pept. Protein Res. 18, 208-213.

36. Sudha, T. S. \& Balaram, P. (1983) Int. J. Pept. Protein Res. 21, 381-385.

37. Urry, D. W., Mitchell, L. W. \& Ohnishi, T. (1974) Biochem. Biophys. Res. Commun. 59, 62-69.

38. Urry, D. W., Mitchell, L. W. \& Ohnishi, T. (1974) Proc. Natl. Acad. Sci. USA 71, 3265-3269.

39. Rao, C. P., Balaram, P. \& Rao, C. N. R (1983) Biopolymers 22, 2091-2104.

40. Maxfield, F. R., Leach, S. J., Stimson, E. R., Powers, S. P. \& Scheraga, H. A. (1979) Biopolymers 18, 2507-2521.

41. Bakir, M. \& Stevens, E. S. (1982) Int. J. Pept. Protein Res. 19, 133-136.

42. Toniolo, C. \& Bonora, G. M. (1976) Can. J. Chem. 54, 70-76. 